\author{
Available online at JECE (Journal of Early Childhood Education) \\ Website: http://journal.uinjkt.ac.id/index.php/jece \\ Permalink/DOI: http://dx.doi.org/10.15408/jece.v1i2.13761 \\ JECE, 1 (2), Desember 2019, 16-28
}

\title{
EVALUASI HASIL AKREDITASI LEMBAGA PAUD SE-KOTA DEPOK
}

\author{
Renti Oktaria ${ }^{1}$, Lukman Hamid ${ }^{2}$, Yuningsih ${ }^{3}$, Suparti ${ }^{3}$ \\ ${ }^{1}$ Universitas Lampung \\ ${ }^{2}$ Sekolah Tinggi Ilmu Tarbiyah Al-Hidayah Tasikmalaya \\ ${ }^{3}$ Dinas Pendidikan Kota Depok \\ corresponding e-mail: renti.oktaria@fkip.unila.ac.id
}

\begin{abstract}
The objectives to be achieved in this study are to analyze (1) descriptive results of accreditation throughout Depok's early childhood education centers in 2018; (2) the results of the distribution of accreditation throughout Depok's early childhood education centers in 11 districts; (3) the results of accreditation based on the length of the school's establishment, land area, and accreditation experience in each kindergarten program. This study uses a mix method research approach with critical analysis methods and library methods, so as to present quantitative data simply and describe it in qualitative data. The findings are as follows: (1) The number of accredited institutions is still dominated by early childhood education centers with TK programs, namely 97 institutions out of 186 institutions that participate in accreditation or as much as 52\% of the total early childhood education centers that participate in accreditation; (2) There is an inequality in the number of accredited institutions in 11 districts in Depok; and (3) High and low accreditation scores do not always relate to the length of standing, land area and experience of institutions in implementing accreditation.
\end{abstract}

Keywords: early childhood education, accreditation, kindergarten program

\begin{abstract}
Abstrak
Tujuan penelitian ini adalah menganalisis (1) hasil deskriptif data akreditasi lembaga PAUD se-Kota Depok tahun 2018; (2) hasil sebaran akreditasi lembaga PAUD se-Kota Depok pada 11 kecamatan; (3) hasil akreditasi berdasarkan lama berdirinya sekolah, luas lahan, dan pengalaman akreditasi di setiap program TK. Penelitian ini menggunakan pendekatan mix method research dengan metode analisis kritis dan metode kepustakaan, dengan menyajikan data kuantitatif secara sederhana dan mendeskripsikannya ke dalam data kualititatif. Diperoleh hasil temuan yakni: (1) Jumlah lembaga yang terakreditasi masih didominasi oleh lembaga PAUD dengan program TK, yakni sebanyak 97 lembaga dari 186 lembaga yang mengikuti akreditasi atau sebanyak 52\% dari total lembaga PAUD yang mengikuti akreditasi; (2) Terdapat ketidakmerataan jumlah lembaga yang terakreditasi di 11 kecamatan yang ada di Kota Depok; dan (3) Nilai akreditasi tinggi dan rendah tidak selalu berkaitan dengan lama berdiri, luas lahan dan pengalaman lembaga dalam melaksanakan akreditasi.
\end{abstract}

Kata kunci: pendidikan anak usia dini, akreditasi, program taman kanak-kanak 



\section{Pendahuluan}

Kementerian Pendidikan dan Kebudayaan menetapkan bahwa seluruh lembaga Pendidikan Anak Usia Dini (PAUD) di Indonesia harus terakreditasi pada 2020. Akreditasi sering dikaitkan dengan standar mutu layanan pendidikan, sehingga lembaga pendidikan anak usia dini di seluruh Indonesia tanpa terkecuali, juga harus menjalani proses akreditasi untuk menjamin mutu layanan di lembaga tersebut.

Dari literatur Indonesia, Kementerian Pendidikan Nasional (2011: 13) mendefinisikan akreditasi sebagai kegiatan penilaian yang dilakukan oleh pemerintah dan/atau lembaga mandiri yang berwenang untuk menentukan kelayakan program dan/atau satuan pendidikan pada jalur pendidikan formal dan nonformal pada setiap jenjang dan jenis pendidikan, berdasarkan kriteria yang telah ditetapkan, sebagai bentuk akuntabilitas publik yang dilakukan dilakukan secara objektif, adil, transparan, dan komprehensif dengan menggunakan instrumen dan kriteria yang mengacu kepada SNP. Akreditasi, sebagaimana evaluasi dan sertifikasi, menurut Pasal 2 Ayat 2 PP No. 19 Tahun 2005 tentang SNP, dilakukan dalam rangka menjamin dan mengendalikan mutu pendidikan. Akreditasi, berdasarkan UU No. 25 Tahun 2009, merupakan program yang dilakukan dalam rangka reformasi layanan yang sasarannya adalah terwujudnya sistem penyelenggaraan pelayanan publik yang layak sesuai dengan asas-asas umum pemerintahan dan korporasi yang baik.

Akreditasi, menurut Montagu (2003: 4), adalah suatu pemantauan eksternal terhadap kualitas atau mutu berlandaskan empat komponen prinsipil, yaitu (1) didasarkan pada standar tertulis dan terpublikasi; (2) pemantauannya dilakukan oleh pakar sejawat; (3) prosesnya dikelola oleh badan atau lembaga independen; dan (4) tujuannya mendorong pengembangan organisasional. Akreditasi adalah proses penilaian dengan indikator tertentu berbasis fakta. Asesor melakukan pengamatan dan penilaian sesuai realitas, tanpa ada manipulasi (Asmani, 2011: 184).

Dalam pandangan Suryana (2007: 3), akreditasi mengarah kepada penyediaan layanan pendidikan yang bermutu dan kedudukannya dapat dijadikan alat regulasi diri (self-regulation) yang memungkinkan sekolah/madrasah (S/M) mengenal dan memahami kekuatan dan kelemahannya. Dengan demikian, idealnya proses dan hasil akreditasi S/M dapat dijadikan (1) bahan refleksi dan evaluasi bagi pemangku kepentingan (stakeholder) S/M tentang kelebihan dan kelemahan S/M, (2) bahan motivasi bagi pihak manajemen S/M untuk melakukan upaya-upaya yang terencana dan berkelanjutan dalam meningkatkan kekuatan-kekuatan yang dimiliki serta memperbaiki kelemahan-kelemahan yang ada, dan (3) dasar yang memberikan keyakinan kepada peserta didik khususnya dan masyarakat pada umumnya bahwa $\mathrm{S} / \mathrm{M}$ telah dan akan melaksanakan berbagai program kerja dengan sumber daya 
yang dimilikinya secara sungguh-sungguh agar terjadi proses pendidikan yang bermutu dan menghasilkan keluaran (output) yang bermutu pula.

Untuk menjamin standar mutu tersebut telah ada badan independen yang mengatur proses akreditasi. Penyusunan dokumen akreditasi mengacu pada instrumen akreditasi dari Badan Akreditasi Nasional (BAN) PAUD dan PNF. Instrumen tersebut bertujuan membina satuan pendidikan agar memenuhi delapan Standar Nasional Pendidikan (SNP). Ketika SNP sudah terpenuhi, barulah lembaga PAUD bisa mengajukan akreditasi ke BAN PAUD dan PNF. Delapan Standar Nasional Pendidikan meliputi standar isi, standar proses, kompetensi lulusan, pendidik dan tenaga kependidikan, sarana dan prasarana, pengelolaan, pembiayaan, dan standar penilaian pendidikan.

Berdasarkan kebijakan BAN PAUD dan PNF pada tahun 2018, yang menjadi Persyaratan Umum Pengajuan Akreditasi PAUD diantaranya: (1) Mengajukan permohonan akreditasi kepada BAN PAUD PNF melalui Sistem Penilaian Akreditasi (Sispena) PAUD dan PNF; (2) Memiliki Izin Penyelenggaraan/ Izin Operasional Program yang diajukan akreditasinya dari Dinas Pendidikan Kabupaten/ Kota, UPT Perijinan, atau lembaga pemerintah lainnya yang berwenang; (3) Memiliki akte Pendirian dari Notaris atau SK Pimpinan Instansi/Lembaga/ Institusi yang berwenang di atasnya; (4) Program yang diajukan akreditasinya telah beroperasi minimal 2 tahun; (5) Diprioritaskan bagi Lembaga yang memiliki NPSN (Nomor Pokok Satuan Pendidikan Nasional) dan mengisi Dapodik; dan (6) Menggunakan prasarana yang didukung dengan dokumen yang sah (Sertifikat Kepemilikan Tanah dan Bangunan, Surat Perjanjian Sewa, Surat Perjanjian Pemanfaatan Prasarana).

Sebagaimana dijabarkan di atas, salah satu dokumen penting dalam pengajuan akreditasi adalah izin operasional dan akta pendirian bangunan. Menjadi sebuah legitimasi bagi sekolah yang telah lama berdiri dibuktikan dengan ijin opersional yang telah lama, memiliki luas lahan yang ideal di atas 500 meter persegi dan berpengalaman dalam proses akreditasi sebelumnya. Fenomena paradigma pemikiran dan ketakutan para pengelola lembaga PAUD yang terjadi di masyarakat demikian adanya, sehingga seringkali dikaitkan bahwa sekolah yang besar dan luas yang akan mendapatkan nilai akreditasi besar, yakni terakreditasi A, dan begitu juga sebaliknya bagi yang sekolahnya kecil. Begitu juga dengan asumsi bahwa sekolah yang baru beroperasi akan mendapatkan nilai akreditasi lebih kecil dibandingkan yang sudah beroperasi lebih lama.

Faktanya, ijin operasional hanya sebagai syarat untuk dapat mengajukan akreditasi pada sistem penilaian akreditasi (Sispena) secara online pada BAN PAUD dan PNF. Demikian juga dengan luas lahan yang menjadi butir ke-32 pada standar 5 (sarana prasarana) yang artinya hanya 1 dari 60 butir penilaian dalam instrumen 
akreditasi, sehingga tidak akan berdampak siginifikan terhadap hasil akreditasi karena masih ada 59 butir lainnya dalam instrumen penilaian akreditasi.

Untuk menjawab asumsi masyarakat khusus pada lingkup Kota Depok, Provinsi Jawa Barat, maka peneliti mencoba mengkaji dan menganalisis hasil akreditasi satuan PAUD se-Kota Depok pada tahun 2018. Adapun rumusan masalah dalam penelitian ini: (1) bagaimana hasil deskriptif data akreditasi satuan PAUD seKota Depok tahun 2018; (2) bagaimana sebaran akreditasi satuan PAUD se-Kota Depok pada 11 kecamatan; (3) bagaimana analisis hasil akreditasi berdasarkan lama berdirinya sekolah, luas lahan, dan pengalaman akreditasi di setiap program TK, RA, KB, dan SPS. Dengan mengkaji penelitian ini diharapkan dapat memberikan masukan membangun bagi Kota Depok khususnya dan bagi Provinsi Jawa Barat, serta hasil penelitian ini juga dapat menjadi landasan penelitian bagi peneliti selanjutnya yang ingin mengkaji lebih dalam tentang analisis hasil akreditasi lembaga PAUD.

\section{Metode}

Sampel yang dipakai adalah populasi, sebanyak 186 lembaga yang terdiri dari program TK sebanyak 97 lembaga, program RA sebanyak 7 lembaga, program KB sebanyak 55 lembaga, dan program SPS sebanyak 27 lembaga. Seluruh populasi adalah satuan PAUD dari hasil akreditasi dari tahap 1 sampai dengan tahap 6 pada tahun 2018 di Provinsi Jawa Barat.

Metode yang digunakan di dalam penelitian ini adalah kualitatif deskriptif dengan cara mendapatkan data faktual dari BAN PAUD dan PNF kemudian dideskripsikan dan dianalisis secara mendalam dari hasil temuan yang ada. Metode analisis kritis yang peneliti maksudkan di sini adalah upaya menyeleksi dengan cara merangkum dan mempertimbangkan masalah sehingga dapat direduksi, direposisi, dan dipaparkan secara sistematis. Sementara itu, metode kepustakaan adalah sebuah metode penelitian yang dilakukan dengan cara mengumpulkan, membaca, mencatat data pustaka serta mengolah bahan penelitian (Mustika, 2008: 3).

Pengumpulan data dilakukan dengan cara menghimpun semua informasi yang akurat dari sumber primer seperti: (1) data hasil akreditasi satuan PAUD di Kota Depok tahun 2018 di ambil dari website BAN PAUD dan PNF; dan (2) data izin operasional, luas lahan, dan pengalaman akreditasi di ambil dari website data referensi Kemendikbud RI dengan cara memasukkan NPSN sekolah satu per satu. Dengan demikian, data yang diolah adalah data yang akurat dan dapat dipertanggungjawabkan. 


\section{Hasil dan Pembahasan}

Dari 186 lembaga PAUD diperoleh data bahwa program yang terakreditasi terdiri dari program Taman Kanak-Kanak (TK) sebanyak 97 lembaga, program Raudhatul Athfal (RA) sebanyak 7 lembaga, program Kelompok Bermain (KB) sebanyak 55 lembaga dan program Satuan PAUD Sejenis (SPS) sebanyak 27 lembaga.

Tabel 1. Rekap Hasil Akreditasi Satuan PAUD Se-Kota Depok Tahun 2018

\begin{tabular}{|c|c|c|c|c|c|}
\hline \multirow{2}{*}{ No. } & \multirow{2}{*}{ Program } & \multicolumn{3}{|c|}{ Status Akreditasi } & \multirow{2}{*}{ Jumlah } \\
\hline & & $\mathbf{A}$ & B & $\mathbf{C}$ & \\
\hline 1. & Taman Kanak-Kanak (TK) & 16 & 66 & 15 & 97 \\
\hline 2. & Raudhatul Athfal (RA) & 2 & 5 & 0 & 7 \\
\hline 3. & Kelompok Bermain (KB) & 0 & 20 & 35 & 55 \\
\hline 4. & Satuan PAUD Sejenis (SPS) & 0 & 14 & 13 & 27 \\
\hline & Total & 18 & 105 & 63 & 186 \\
\hline
\end{tabular}

Berdasarkan tabel di atas, didapatkan data bahwa program TK menjadi program terbanyak yang terakreditasi dengan jumlah 97 lembaga yang terdiri dari 16 lembaga terakreditasi A, 66 lembaga terakreditasi B dan 15 lembaga terakreditasi C. Program KB menjadi program terbanyak kedua setelah program TK, yakni dengan jumlah 55 lembaga dengan rincian 20 lembaga terakreditasi B dan 35 lembaga terakreditasi C. Program SPS menjadi program terakreditasi di urutan ketiga setelah program KB, yakni dengan jumlah 27 lembaga yang terdiri dari 14 lembaga terakreditasi B dan 13 lembaga terakreditasi C. Program RA menjadi program paling rendah yang mengajukan akreditasi di Kota Depok tahun 2018, yakni hanya sebanyak 7 lembaga dengan rincian 2 lembaga terakreditasi A dan 5 lembaga terakreditasi B. Dengan data yang ada, dapat dilihat presentase masing-masing program seperti gambar di bawah ini.

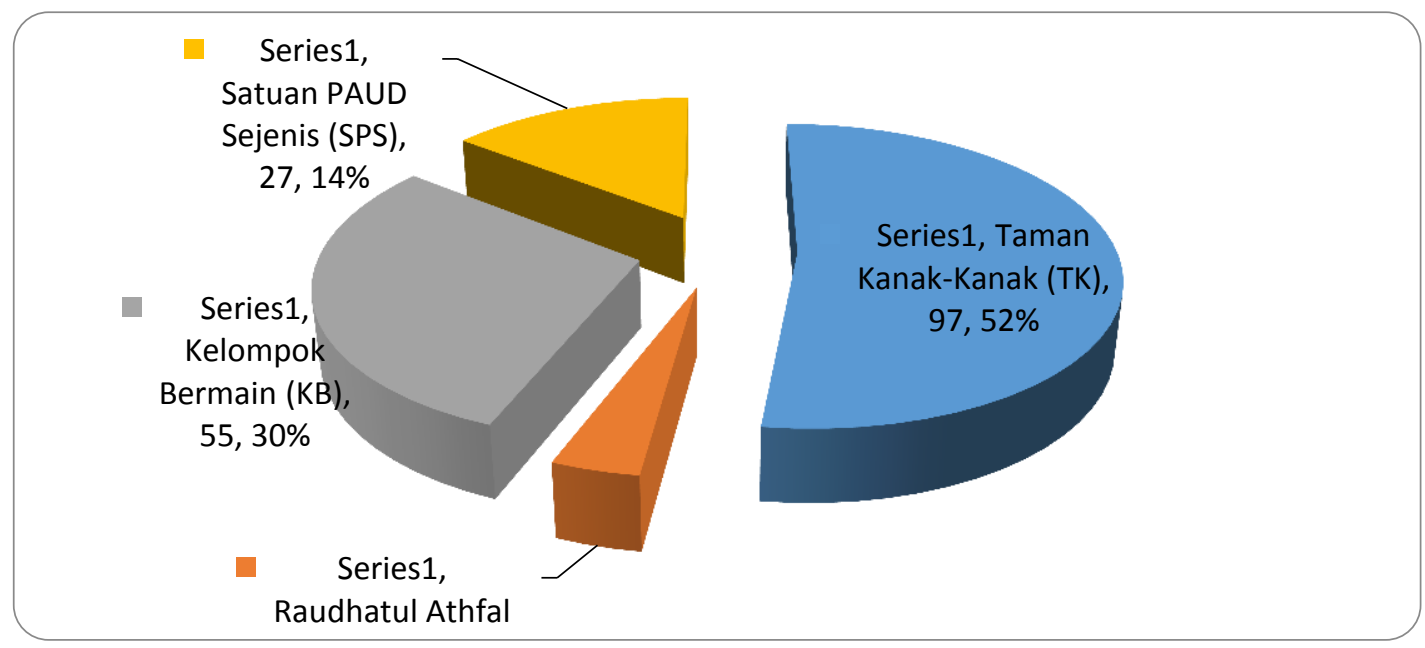

Gambar 1. Diagram Presentase Hasil Akreditasi Satuan PAUD Se-Kota Depok Tahun 2018

Berdasarkan gambar di atas, diperoleh data dari 186 lembaga PAUD yang terakreditasi dari tahap 1 sampai dengan tahap 6 di Kota Depok tahun 2018 
didominasi oleh program Taman Kanak-Kanak sebanyak 52\% (97 lembaga), program Raudhatul Athfal sebanyak 4\% (7 lembaga), program Kelompok Bermain sebanyak 30\% (55 lembaga) dan program Satuan PAUD Sejenis sebanyak 14\% (27 lembaga).

Dengan demikian, program yang lebih banyak terakreditasi adalah TK. Artinya, program TK menjadi program terbanyak mengajukan akreditasi dikarenakan jumlah program TK memang mendominasi di Kota Depok, yakni sebanyak 685 lembaga. Sementara itu, lembaga kedua yang terbanyak terakreditasi adalah program KB, juga secara statistik program ini adalah terbanyak kedua setelah program TK, yakni sebanyak 364 lembaga PAUD dengan program KB yang ada di Kota Depok.

\section{Analisis Hasil Akreditasi Per Kecamatan di Kota Depok Tahun 2018}

Berdasarkan hasil deskriptif data pada poin 1 didapati bahwa program terbanyak yang terakreditasi adalah program TK. Selanjutnya, pada poin 2 ini akan dianalisis bagaimana sebaran lembaga PAUD yang terakreditasi disetiap kecamatan seperti yang dijabarkan pada tabel di bawah ini.

Tabel 2. Hasil Akreditasi Rincian Hasil Akreditasi Satuan PAUD di Kota Depok Tahun 2018 Berdasarkan Kecamatan dan Kelompok Program (TK, RA, KB, dan SPS)

\begin{tabular}{|l|l|l|l|l|l|l|l|l|l|l|l|l|l|l|}
\hline \multirow{2}{*}{ No. } & \multirow{2}{*}{ Kecamatan } & \multicolumn{3}{|c|}{ TK } & \multicolumn{3}{|c|}{ RA } & \multicolumn{3}{|c|}{ KB } & \multicolumn{3}{|c|}{ SPS } & \multirow{2}{*}{ Jumlah } \\
\hline & & $\mathbf{A}$ & $\mathbf{B}$ & $\mathbf{C}$ & $\mathbf{A}$ & $\mathbf{B}$ & $\mathbf{C}$ & $\mathbf{A}$ & $\mathbf{B}$ & $\mathbf{C}$ & $\mathbf{A}$ & $\mathbf{B}$ & $\mathbf{C}$ & \\
\hline 1 & Beji & 1 & 4 & & & & & & & 2 & & & & $\mathbf{7}$ \\
\hline 2 & Bojongsari & & 1 & 1 & & & & & 3 & 4 & & 1 & & $\mathbf{1 0}$ \\
\hline 3 & Cilodong & 3 & 11 & 1 & & & & & 3 & 5 & & 3 & & $\mathbf{2 6}$ \\
\hline 4 & Cimanggis & 3 & 5 & 1 & 2 & 2 & & & 1 & - & & 2 & 2 & $\mathbf{1 8}$ \\
\hline 5 & Cinere & 1 & & 1 & & & & & 3 & 1 & & & & $\mathbf{6}$ \\
\hline 6 & Cipayung & & 8 & 3 & & & & & 2 & 5 & & 2 & 1 & $\mathbf{2 1}$ \\
\hline 7 & Limo & 1 & 5 & & & & & & 1 & - & & 2 & & $\mathbf{9}$ \\
\hline 8 & Pancoran Mas & & 6 & & & 1 & & & 4 & 5 & & & 3 & $\mathbf{1 9}$ \\
\hline 9 & Sawangan & & 4 & & & & & & & & & & 1 & $\mathbf{5}$ \\
\hline 10 & Sukmajaya & 6 & 10 & 2 & & 1 & & & 2 & 5 & & 4 & 6 & $\mathbf{3 6}$ \\
\hline 11 & Tapos & 1 & 12 & 6 & & 1 & & & 1 & 8 & & & & $\mathbf{2 9}$ \\
\hline Total & & $\mathbf{1 6}$ & $\mathbf{6 6}$ & $\mathbf{1 5}$ & $\mathbf{2}$ & $\mathbf{5}$ & $\mathbf{0}$ & $\mathbf{0}$ & $\mathbf{2 0}$ & $\mathbf{3 5}$ & $\mathbf{0}$ & $\mathbf{1 4}$ & $\mathbf{1 3}$ & $\mathbf{1 8 6}$ \\
\hline
\end{tabular}

Berdasarkan tabel di atas, diperoleh data bahwa dari 11 kecamatan yang merupakan sebaran wilayah dari 186 lembaga PAUD yang terakreditasi diasumsikan masing-masing kecamatan dapat mengajukan minimal 16 lembaga PAUD untuk diakreditasi, tetapi faktanya hanya beberapa kecamatan yang memenuhi kuota tersebut. Disisi lain, terdapat 3 kecamatan dengan pengajuan akreditasi lembaga terbanyak seperti Kecamatan Sukmajaya, Tapos dan Cilodong. 
Kecamatan dengan pengajuan akreditasi terbanyak adalah Kecamatan Sukmajaya, sebanyak 36 lembaga terakreditasi pada tahun 2018 dengan rincian 18 program TK, 1 program RA, 7 program KB, dan 10 program SPS. Kecamatan Tapos dengan jumlah lembaga terakreditasi 29 lembaga dan Kecamatan Cilodong dengan jumlah lembaga terakreditasi sebanyak 26 lembaga. Ketiga kecamatan tersebut berhasil menyumbangkan lebih dari 20 lembaga PAUD sebagai pengaju akreditasi di Kota Depok tahun 2018. Kesuksesan 3 kecamatan sebagai penyumbang lembaga PAUD terbanyak pada akreditasi tahun 2018 tidak lepas dari kerja keras para pengawas dan penilik di kecamatan tersebut.

Kemudian, diperoleh data 3 kecamatan dengan pengajuan akreditasi paling sedikit adalah Kecamatan Beji, Cinere, dan Sawangan. Kecamatan Beji mengajukan 7 lembaga PAUD untuk diakreditasi dengan rincian, sebanyak 5 lembaga pada program TK dan 2 lembaga pada program KB. Kecamatan Cinere mengajukan 6 lembaga PAUD untuk diakreditasi dengan rincian 2 lembaga pada program TK dan 4 lembaga pada program KB. Kecamatan Sawangan menjadi kecamatan dengan pengajuan akreditasi terkecil yakni hanya 5 lembaga PAUD dengan rincian 4 lembaga pada program TK dan 1 lembaga pada program SPS.

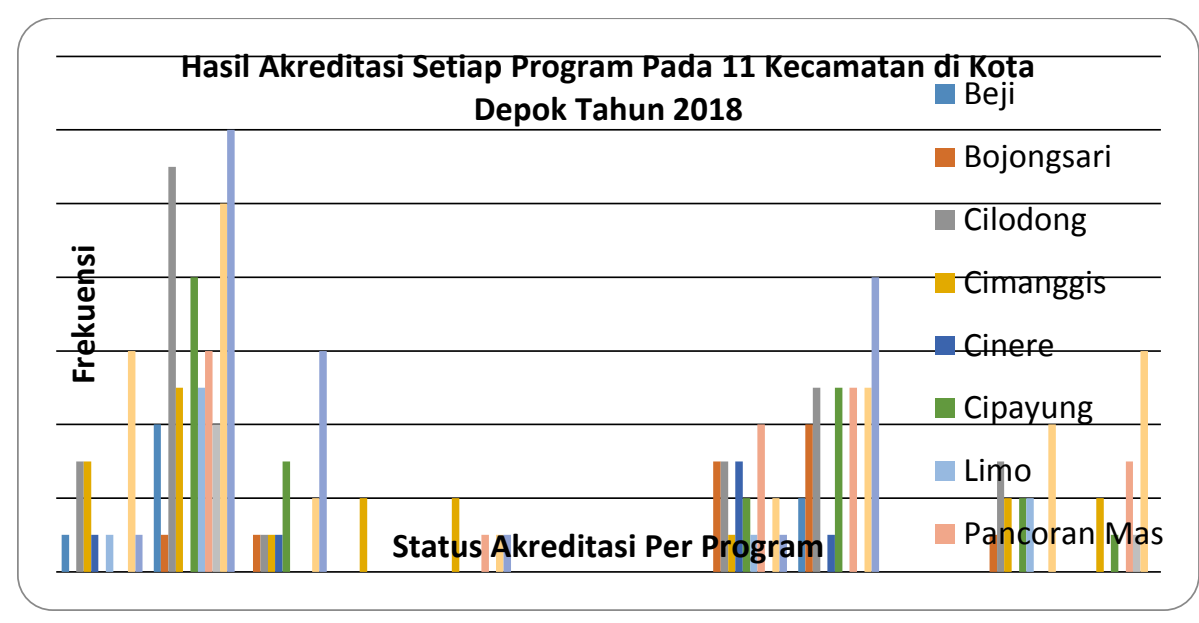

Gambar 2. Sebaran Lembaga PAUD Yang Terakreditasi di 11 Kecamatan, Kota Depok Tahun 2018

Berdasarkan penjelasan sebelumnya, didapati bahwa dari 11 kecamatan sebaran lembaga PAUD yang mengajukan akreditasi adalah tidak merata. Adapun presentase jumlah lembaga PAUD yang telah terakreditasi di Kota Depok pada tahun 2018 dapat dilihat pada gambar di bawah ini. 


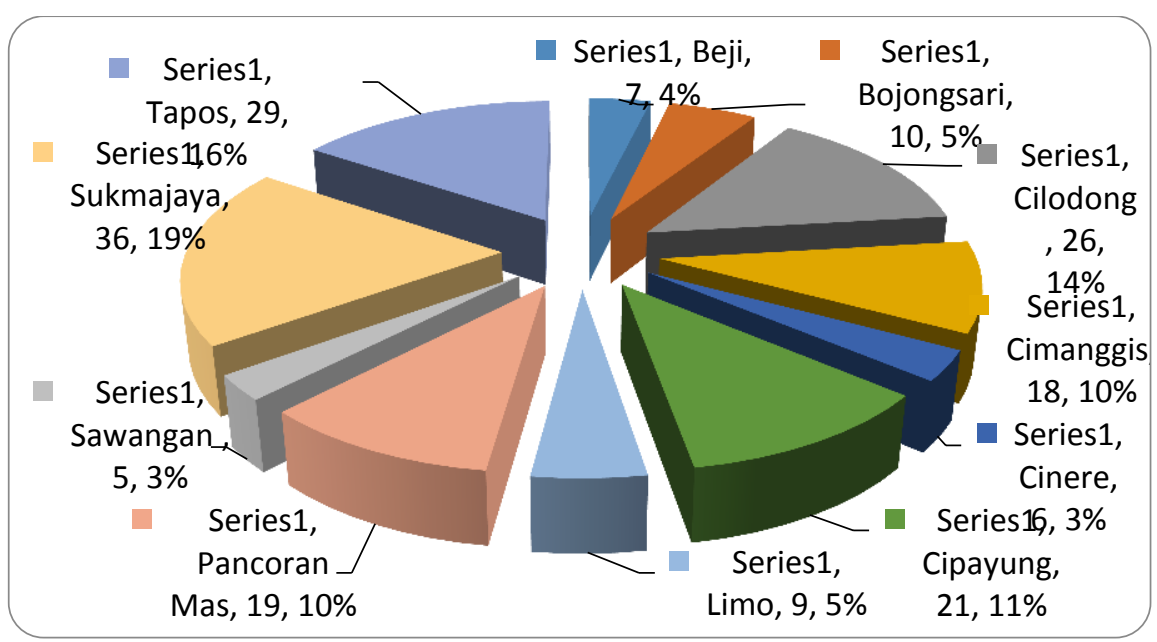

Gambar 3. Presentase Jumlah Satuan PAUD Yang Terakreditasi di Kota Depok Pada Tahun 2018

Berdasarkan diagram lingkaran di atas, didapatkan fakta bahwa dari 11 kecamatan terdapat 4 kecamatan diatas $10 \%$ pengajuan akreditasi, ada 4 kecamatan diposisi $5-10 \%$ pengajuan akreditasinya, dan sisanya terdapat 3 kecamatan menduduki peringkat terbawah yakni dibawah 5\% dalam mengajukan akreditasi untuk lembaga PAUD se-Kota Depok pada tahun 2018. Kecamatan yang diatas $10 \%$ dan menjadi kecamatan terbanyak adalah Sukmajaya sebanyak 19\%, sedangkan kecamatan diposisi terbawah adalah Sawangan dan Cinere dengan presentase 3\%.

Ketidakmerataan pengajuan akreditasi ini didasarkan pada beberapa faktor. Pertama, faktor yang mempengaruhi sedikitnya pengajuan akreditasi di tiga kecamatan ini disebabkan pada tahun sebelumnya telah banyak lembaga di kecamatan tersebut yang sudah terakreditasi dan dalam proses menunggu akreditasi ulang. Kedua, faktor sosialiasi akreditasi dengan sistem penilaian akreditasi (sispena) terbaru juga nampaknya belum merata sehingga menyebabkan masih banyak lembaga yang belum memberanikan diri untuk mengajukan akreditasi.

Bukti bahwa ada ketidakmerataan hasil akreditasi BAN PAUD dan PNF pada 11 kecamatan di Kota Depok dapat didasari oleh fakta dimana fungsi pengawas atau penilik pemerintah berperan aktif dalam hal bimbingan akreditasi. Sebagaimana dinyatakan oleh Dirhana (1999:11) dimana ada 5 jenis pengawasan yang mana salah satunya adalah pengawasan aparat pemeriksa fungsional, dalam hal ini ialah Pengawas dan Penilik yang dituntut untuk berperan aktif menjalankan fungsinya dalam mengawasi dan melakukan bimbingan kepada seluruh lembaga binaannya dalam menghadapi akreditasi. 


\section{Analisis Hasil Akreditasi Program TK di Kota Depok Berdasarkan Lama Berdiri, Luas Lahan dan Pengalaman Akreditasi}

Untuk mengetahui apakah tinggi dan rendahnya nilai akreditasi suatu lembaga didasari lama berdirinya suatu lembaga, luas lahan lembaga, dan pengalaman lembaga dalam pelaksanaan akreditasi sebelumnya, maka diperlukan analisis data untuk menjawab hipotesa penelitian ini. Hipotesa pertama, lembaga PAUD yang telah lama berdiri akan memiliki nilai akreditasi yang lebih tinggi dibandingkan lembaga PAUD yang baru saja berdiri. Hipotesa kedua, hanya lembaga PAUD yang memiliki luas lahan lebih dari 300 meter persegi akan memperoleh nilai akreditasi A dibandingkan lembaga PAUD yang hanya memiliki luas lahan kurang dari 100 meter persegi. Hipotesa ketiga, lembaga PAUD yang telah memiliki pengalaman akreditasi sebelumnya akan memperoleh nilai akreditasi dibandingkan lembaga PAUD yang belum pernah memiliki pengalaman akreditasi sebelumnya.

Untuk mengetahui adakah hubungannya ketiga faktor tersebut terhadap hasil akreditasi lembaga PAUD se-Kota Depok pada tahun 2018, maka dikaji data hasil akreditasi ini menjadi sebuah tabel yang menjabarkan perbandingan hasil akreditasi dengan data terperinci mengenai lama berdiri, luas lahan dan pengalaman akreditasi lembaga PAUD pada program TK sebagai sampel untuk analisis dan evaluasi hasil akreditasi di Kota Depok tahun 2018.

Tabel 3. Perbandingan Hasil Akreditasi Program TK Berdasarkan Lama Berdiri

\begin{tabular}{|l|l|c|c|c|c|}
\hline \multirow{2}{*}{ No. } & \multirow{2}{*}{ Lama Berdiri } & \multicolumn{3}{|c|}{ Status Akreditasi } & \multirow{2}{*}{ Jumlah } \\
\cline { 3 - 5 } & & A & B & C & \\
\hline 1. & $<5$ tahun & 3 & 14 & 4 & 12 \\
\hline 2. & $5-10$ tahun & 1 & 10 & 1 & 3 \\
\hline 3. & $11-15$ tahun & 1 & 1 & 1 & 7 \\
\hline 4. & $16-20$ tahun & 3 & 4 & 0 & 4 \\
\hline 5. & $>20$ tahun & 0 & 3 & 8 & 50 \\
\hline 6. & Tidak Ada Data & 8 & 34 & 15 & 97 \\
\hline \multicolumn{2}{|l|}{ Total } & 16 & 66 & 8 & 12 \\
\hline
\end{tabular}

Berdasarkan tabel data di atas, diketahui dengan jelas bahwa dari 97 lembaga PAUD program TK yang telah melaksanakan akreditasi tahun 2018 terdapat 16 lembaga mendapatkan akreditasi A, 66 lembaga dengan akreditasi B dan 15 lembaga terakreditasi C. Nilai akreditasi lebih didominasi dengan nilai B, yang menunjukkan bahwa lembaga PAUD program TK di Kota Depok telah memenuhi standar penjaminan mutu lembaga. Nilai akreditasi A dan C dengan jumlah lembaga yang hampir sama. 
Kemudian jika dikaji berdasarkan lama berdirinya lembaga yang mendapatkan nilai akreditasi A, dari 16 lembaga didapatkan data sebanyak 8 lembaga dengan data valid ditemukan fakta bahwa lembaga yang telah berdiri kurang dari 5 tahun pun dapat memperoleh nilai akreditasi A sama dengan lembaga yang telah berdiri selama lebih dari 20 tahun. Begitu juga hasil akreditasi dengan nilai B, diperoleh fakta bahwa sebanyak 32 lembaga dari 66 lembaga memiliki data yang lengkap mengenai lama berdiri, sehingga dapat disimpulkan bahwa sebagian besar lembaga yang baru berdiri kurang dari 5 tahun juga mendapatkan nilai akreditasi B. Akan tetapi, menjadi catatan besar ketika mendapatkan fakta bahwa lembaga yang telah berdiri lebih dari 20 tahun juga masih mendapatkan nilai akreditasi B. Demikian juga dengan hasil akreditasi nilai C yang didapatkan fakta bahwa masih ada lembaga yang mendapatkan nilai C meskipun telah berdiri lebih dari 20 tahun.

Dari hasil penjabaran di atas, dapat disimpulkan sementara bahwa masih ada lembaga PAUD program TK yang mendapatkan nilai akreditasi C meskipun telah berdiri lebih dari 20 tahun, sejumlah besar lembaga PAUD yang berdiri kurang dari 5 tahun sejak 2018 telah berhasil mendapatkan nilai akreditasi B, dan sebagian besar dari lembaga PAUD yang berdiri kurang dari 5 tahun sudah berhasil mendapatkan nilai akreditasi A yang setara dengan lembaga PAUD lainnya yang telah berdiri lebih dari 20 tahun. Hal ini menunjukkan bahwa hipotesa yang menyatakan bahwa semakin lama berdirinya suatu lembaga maka peluang mendapatkan nilai akreditasi A akan semakin besar, dan sebaliknya untuk lembaga yang berdiri kurang dari 5 tahun akan sulit mendapatkan nilai akreditasi A. Faktanya adalah hasil akreditasi lembaga PAUD program TK pada Kota Depok tahun 2018 yang dengan jelas bahwa terdapat 4 lembaga yang berhasil mendapatkan nilai akreditasi A dan baru berdiri kurang dari 5 tahun.

Tabel 4. Perbandingan Hasil Akreditasi Program TK Berdasarkan Luas Lahan

\begin{tabular}{|c|c|c|c|c|c|}
\hline \multirow{2}{*}{ No. } & \multirow{2}{*}{ Luas Lahan } & \multicolumn{3}{|c|}{ Status Akreditasi } & \multirow{2}{*}{ Jumlah } \\
\hline & & $\mathbf{A}$ & B & $\mathrm{C}$ & \\
\hline 1. & $\leq 100 \mathrm{~m}^{2}$ & 2 & 17 & 8 & 27 \\
\hline 2. & $101-200 \mathrm{~m}^{2}$ & 0 & 5 & 2 & 7 \\
\hline 3. & $201-300 \mathrm{~m}^{2}$ & 1 & 4 & 1 & 6 \\
\hline 4. & $301-400 \mathrm{~m}^{2}$ & 1 & 1 & 2 & 4 \\
\hline 5. & $401-500 \mathrm{~m}^{2}$ & 0 & 3 & 0 & 3 \\
\hline 6. & $>500 \mathrm{~m}^{2}$ & 2 & 6 & 0 & 8 \\
\hline 7. & Tidak Ada Data & 10 & 30 & 2 & 42 \\
\hline & Total & 16 & 66 & 15 & 97 \\
\hline
\end{tabular}

Berdasarkan tabel data di atas, diperoleh data bahwa dari 27 lembaga yang memiliki luas lahan kurang dari 100 meter persegi terdapat 2 lembaga yang 
mendapatkan nilai akreditasi A, sebanyak 17 lembaga mendapatkan nilai akreditasi B, dan sebanyak 8 lembaga memperoleh nilai akreditasi C. Selanjutnya, sebanyak 8 lembaga memiliki luas lahan lebih dari 500 meter persegi, dengan rincian sebanyak 2 lembaga memperoleh nilai akreditasi A dan sebanyak 6 lembaga memperoleh nilai akreditasi B. Akan tetapi, tidak ada lembaga dengan luas lahan lebih dari 500 meter persegi yang mendapatkan nilai akreditasi C, hanya saja masih ditemukan lembaga dengan luas lahan antara 301400 meter persegi yang memperoleh nilai akreditasi C. Kemudian sebaran data lainnya relatif sedikit dibandingkan data dengan luas lahan terbesar dan terkecil.

Jika dianalisis berdasarkan fakta temuan yang ada, maka dapat disimpulkan bahwa masih ada lembaga dengan luas lahan yang kurang dari 100 meter persegi namun mendapatkan nilai akreditasi A. Fakta ini berbanding terbalik dengan temuan bahwa masih ada lembaga dengan luas lahan diantara 301-400 meter persegi yang mendapatkan nilai akreditasi C. Fakta lainnya yang menarik adalah lebih dari setengah jumlah lembaga yang memperoleh nilai akreditasi B ternyata memiliki luas lahan kurang dari 100 meter persegi. Dengan demikian, hipotesa yang menyatakan bahwa hanya lembaga PAUD yang memiliki luas lahan lebih dari 300 meter persegi akan memperoleh nilai akreditasi A dibandingkan lembaga PAUD yang hanya memiliki luas lahan kurang dari 100 meter persegi telah terbantahkan dengan data pada tabel hasil akreditasi di atas. Faktanya masih ada lembaga PAUD yang mampu memperoleh nilai akreditasi A meskipun dengan luas lahan kurang dari 100 meter persegi. Diasumsikan bahwa bisa jadi luas lahannya memang minimalis, tetapi terdapat dua lantai dan faktor lainnya yang menunjang lembaga tersebut memperoleh nilai akreditasi A, atau belum terekamnya data luas lahan yang sesungguhnya pada website data dinas pendidikan Kota Depok.

Tabel 5. Perbandingan Hasil Akreditasi Program TK Berdasarkan Pengalaman Akreditasi

\begin{tabular}{|c|c|c|c|c|c|}
\hline \multirow{2}{*}{ No. } & \multirow{2}{*}{$\begin{array}{c}\text { Pengalaman } \\
\text { Akreditasi }\end{array}$} & $\mathbf{A}$ & $\mathbf{B}$ & \multirow{2}{*}{ Jumlah } \\
\cline { 3 - 5 } & Pernah & 12 & 43 & $\mathbf{C}$ & \\
\hline 1. & Belum Pernah & 4 & 23 & 11 & 39 \\
\hline 2. & & 16 & 66 & 15 & 97 \\
\hline & & &
\end{tabular}

Berdasarkan tabel data di atas diperoleh data bahwa sebanyak 38 lembaga PAUD dari 97 lembaga PAUD yang telah terakreditasi pada tahun 2018 di Kota Depok diketahui belum pernah memiliki pengalaman akreditasi, sisanya sebanyak 59 lembaga PAUD telah memiliki pengalaman akreditasi sebelumnya. Melihat data yang ada, dari 59 lembaga PAUD yang masuk dalam kategori lembaga yang telah memiliki pengalaman akreditasi, sebanyak 12 lembaga mendapatkan nilai akreditasi A, sebanyak 43 lembaga mendapatkan nilai 
akreditasi B, dan sebanyak 4 lembaga mendapatkan nilai C. Fakta lainnya dari kelompok lembaga PAUD dengan kategori lembaga yang belum pernah memiliki pengalaman akreditasi, yakni sebanyak 4 lembaga mendapatkan nilai A, sebanyak 23 lembaga mendapatkan nilai B, dan sebanyak 11 lembaga mendapatkan nilai $\mathrm{C}$.

Dari perbandingan hasil akreditasi program TK berdasarkan pengalaman akreditasi di atas, dapat disimpulkan bahwa hipotesa yang menyatakan lembaga PAUD yang telah memiliki pengalaman akreditasi sebelumnya akan memperoleh nilai akreditasi dibandingkan lembaga PAUD yang belum pernah memiliki pengalaman akreditasi sebelumnya tidak terbukti. Faktanya, ada 4 lembaga yang belum memiliki pengalaman akreditasi sebelumnya namun berhasil memperoleh nilai akreditasi A. Sementara itu, masih ada 4 lembaga yang telah berpengalaman tetapi masih saja memperoleh nilai akreditasi C. Ini membuktikan bahwa tidak ada hubungannya lembaga yang telah berpengalaman akreditasi akan mendapatkan nilai akreditasi yang lebih baik dari lembaga yang belum memiliki pengalaman akreditasi.

\section{Simpulan}

Berdasarkan analisis data temuan dan pembahasan di atas, dapat disimpulkan tiga hal yaitu: (1) Jumlah lembaga yang terakreditasi masih didominasi oleh lembaga PAUD dengan program TK, yakni sebanyak 97 lembaga dari 186 lembaga yang mengikuti akreditasi atau sebanyak 52\% dari total lembaga PAUD yang mengikuti akreditasi; (2) Terdapat ketidakmerataan jumlah lembaga yang terakreditasi di 11 kecamatan yang ada di Kota Depok, dibuktikan dengan fakta bahwa kecamatan Sukmajaya jauh lebih unggul dibandingkan kecamatan lainnya dalam jumlah lembaga yang terakreditasi; dan (3) Nilai akreditasi tinggi dan rendah tidak selalu berkaitan dengan lama berdiri, luas lahan dan pengalaman lembaga dalam melaksanakan akreditasi, dibuktikan dengan masih ada lembaga yang berhasil memperoleh nilai akreditasi A meskipun berdiri kurang dari 5 tahun, luas lahan kurang dari 100 meter persegi dan belum berpengalaman melaksanakan akreditasi sebelumnya.[]

\section{Daftar Rujukan}

Arikunto, Suharsimi. (2006). Prosedur Penelitian Suatu Pendekatan Praktik. Jakarta: PT. Rineka Cipta.

Asmani, J. M. (2011). Tips Praktis Membangun dan Mengolah Administrasi. Yogyakarta: Diva Press.

Creswell, John. (2014). Research Design. Yogyakarta: Pustaka Pelajar. 
Dirhana, H. (1999). Pemeriksaan dalam Pengawasan. Bandung: Inspektorat Wilayah Jawa Barat.

Kementerian Pendidikan Nasional. (2011). Standar Nasional Pendidikan. Direktorat Jenderal Pendidikan. Jakarta: Kemendiknas.

Montagu, Dominic. (2003). Accreditation and Other External Quality Assessment Systems for Healthcare. London: British Government's Department For International Development (DFID).

Mustika, Z. (2008). Metode Penelitian Kepustakaan. Jakarta: Yayasan Obor Indonesia.

Sugiyono. (2011). Metode Penelitian Pendidikan: Pendekatan Kuantitatif, Kualitatif, dan $R \mathcal{E D}$, Cet. VIII. Bandung: Alfabeta

Suryana, Asep. (2007). "Akreditasi, Sertifikasi, dan Upaya Penjaminan Mutu Pendidikan", unpublished article. 